\title{
GRB2 wt Allele
}

National Cancer Institute

\section{Source}

National Cancer Institute. GRB2 wt Allele. NCI Thesaurus. Code C52395.

Human GRB2 wild-type allele is located within $17 q 24-q 25$ and is approximately $88 \mathrm{~kb}$ in length. This allele, which encodes growth factor receptor-bound protein 2, plays a role in epidermal growth factor-mediated signal progression. 